Research article

\title{
COMPARATIVE ANALYSIS OF PARAMETERS OF INTRAOPERATIVE AND POSTOPERATIVE PAIN IN BITCHES UNDERGOING LAPAROSCOPIC OR CONVENTIONAL OVARIECTOMY
}

\author{
VASILJEVIĆ Maja ${ }^{1 *}$, RISTANOVIĆ Dragan ${ }^{1}$, JOVANOVIĆ Milan 1 , DAVITKOV \\ Darko ${ }^{1}$, BOŠNJAK Ivan ${ }^{2}$, KRSTIĆ Vanja ${ }^{1}$, STANIMIROVIĆ Zoran ${ }^{3}$ \\ ${ }^{1}$ Department of Equine, Small Animal, Poultry and Wild Animal Diseases, Faculty of Veterinary \\ Medicine, University of Belgrade, Bul. oslobodjenja 18, 11000 Belgrade, Serbia; ${ }^{2}$ State secretary, \\ Ministry of public administration and local self-government Republic of Serbia; ${ }^{3}$ Department of \\ Biology, Faculty of Veterinary Medicine, University of Belgrade, Bul. oslobodjenja 18, 11000 Belgrade, \\ Serbia
}

(Received 19 January; Accepted 10 June 2015)

The aim of this study was to evaluate the parameters of intraoperative and postoperative pain in bitches undergoing laparoscopic or conventional ovariectomy. The study was conducted on 20 healthy, adult bitches of medium and large breeds. All the bitches were subjected to the same anesthetic protocol. Carprofen was applied preoperatively, and general anaesthesia was carried out with a combination of medetomidine, propofol and sevoflurane. The bitches were divided into two groups of 10 individuals each. The first group underwent conventional ovariectomy while the second one was subjected to the laparoscopic procedure. The intensity of intraoperative pain was estimated at different time points by measuring changes in heart and respiratory rate, arterial blood pressure, and body temperature. A multifactor pain scale was used to assess the intensity of postoperative pain. Dogs in the group which was scheduled for conventional ovariectomy (COV group) responded to painful intra-operative stimuli with increased heart rate and respiratory rate. Arterial blood pressure and body temperature decrease was detected in COV group. Laparoscopic ovariectomy induced less intra- and postoperative pain when compared to conventional ovariectomy. Beside that, the total anaesthesia time and postoperative recovery were shorter in dogs that underwent laparascopic ovariectomy.

Key words: bitches, laparoscopy, ovariectomy, pain

\section{INTRODUCTION}

Ovariectomy is the surgical removal of both ovaries. It is performed in bitches to rule out a full cycle, prevent tumors of the mammary gland and purulent processes in the uterus [1]. Ovariectomy can be performed by conventional surgical methods

\footnotetext{
*Corresponding author: e-mail: majavasiljevicmaja@gmail.com
} 
or by laparoscopic surgery [2]. Conventional ovariectomy is a very common surgical procedure in veterinary practice [3]. Today more and more dog owners are seeking for laparoscopic ovariectomy due to the undeniable advantages such as: less painful intervention than conventional ovariectomy, quick patients' recovery and return to normal activities [4]. The first laparoscopic procedure in veterinary medicine was described by Wildt and Lawer's in 1985 [5] and referred to the sterilization of bitches. The intensity of postoperative pain after conventional ovariectomy is associated with greater tissue damage during the incision of the skin [6]. In laparoscopic ovariectomy, the skin incision is smaller and the painful stages that are inevitable in conventional ovariectomy (i.e. withdrawal of ligaments and extraperitoneal positioning of the ovaries) are avoided, resulting in less intra and postoperative pain [7].

The pain can be defined as an unpleasant sensory and emotional experience associated with an existing injury, which can range from mild, localized discomfort to pain. Behavior during expression of pain is different from physiological behavior, and appetite, body position, movement, and response to touch are changed in painful situations. Increased salivation, mydriasis, tachycardia, depression, and avoidance of contact are some of the signs of pain [8]. Postoperative pain management is extremely important and affects the recovery time, quality of life and success of the surgical procedure [9]. Acute pain changes the metabolic and hemodynamic system [10]. Scales for the assessment of pain intensity are well developed. They take into account the different species and different pathological processes that cause pain and as such, are very diverse [11]. In most cases, they contain a combination of subjective parameters, such as behavioral changes (e.g. change in appetite, depression, aggression, vocalization, response to touch, etc.) and objective parameters (e.g. changes in heart rate).

The anaesthesia protocol used in this study (a combination of medetomidine, propofol and sevoflurane) is often used in everyday practice $[12,13]$, however, there are no published reports on comparison of parameters of intra- and postoperative pain when used in bitches undergoing conventional or laparoscopic ovariectomy.

\section{MATERIAL AND METHODS}

\section{Dogs}

Twenty female dogs of different breeds, aged from 7 months to 3 years, weighing 5 to $35 \mathrm{~kg}$ were scheduled for an ovariectomy. They were randomly divided into two groups of ten bitches each. The first group was scheduled for conventional ovariectomy (COV) and the second group for the laparoscopic ovariectomy (LOV). Preoperative preparation was identical for both groups of bitches. After a general clinical examination, venous blood samples were collected for complete blood count, and the serum biochemistry profile including blood urea nitrogen, creatinine, total protein, albumin, glucose, creatin kinase, alkaline phosphatase, aspartate aminotransferase and alanine aminotransferase (data not shown). The bitches were classified as ASA 
I category according to the American Association of Anesthesiologists. The study was approved by the local Ethics Committee (No 7/2015). The owners were fully informed and agreed with the procedure.

\section{Analgesia and anaesthesia}

All the dogs were given carprofen $4 \mathrm{mg} / \mathrm{kg}$ s.c. (Rymadil, Pfizer Animal Health, USA). After 20 minutes, an intravenous catheter was placed and the dogs were premedicated with medetomidine $0.03 \mathrm{mg} / \mathrm{kg}$ i.v. (Domitor, Pfizer Animal Health, USA). The dogs were induced to anaesthesia with propofol $2 \mathrm{mg} / \mathrm{kg}$ i.v. (Diprivan, AstraZeneca, UK) and endotracheally intubated. Anaesthesia was maintained with sevoflurane (Sevorane, Abbot, Canada). Sevoflurane concentration (vaporizer setting) was $2.5-3 \%$ in COV group, while in the LOV group the concentration was $1.5-2 \%$. Anaesthesia time (from intubation to extubation) was 35 to 55 minutes. Dogs were administered Hartmann's solution at $5 \mathrm{ml} / \mathrm{kg} / \mathrm{h}$ i.v. (Hartmann's solution, Hemofarm AD, Serbia) during surgery. After the surgery, the dogs were given atipamezol $0.015 \mathrm{mg} / \mathrm{kg}$ i.m. (Antisedan, Orion Pharma, Finland) to antagonize the effects of medetomidine.

Dogs in COV group received ketamine $2 \mathrm{mg} / \mathrm{kg}$ i.v. (Ketamidor, Marlo farma, Belgrade) at the time of withdrawal of the left ovarian ligament. They also received tramadol $10 \mathrm{mg} / \mathrm{kg}$ i.m. (Trodon, Hemofarm A.D. Belgrade) six hours after the end of surgery (after the last evaluation of postoperative pain score).

\section{Monitoring of pain}

The intensity of the intraoperative pain was estimated at different time points: intubation, incision, withdrawal of left ovarian ligament, withdrawal of right ovarian ligament, suturing of the skin and extubation, by measuring changes in heart rate, arterial blood pressure, respiratory rate and body temperature.

The intensity of postoperative pain was assessed by the same observer with the aid of a multifactor pain scale at regular time intervals at 15 and 30 minutes and 1, 3, and 6 hours postoperatively. The observer evaluated four parameters: signs of crying and whimpering, movements, restlessness and discomfort and response to firm pressure applied adjacent to the surgical wound. Ranked scores were summed and presented in tables. Multifactor pain scale scores range from 0 to 9 , where 0 indicates no pain and 9 indicates the worst pain possible.

\section{Statistical analysis}

The results are presented as mean values \pm standard deviation. Statistical analysis was carried out using GraphPad Prism statistical package 6 (GraphPad Software, California, USA) using one-way analysis of variance (ANOVA) and dependent T test. A $p$ value of less than 0.05 was considered significant. 


\section{RESULTS}

In bitches, which underwent conventional ovariectomy, the heart rate increased significantly during withdrawal of the left ovarian ligament $(109.5 \pm 3.17$ beats $/ \mathrm{min})$ comparing to the first phase $(80.5 \pm 3.14$ beats $/ \mathrm{min}, p<0.05$; Table 1$)$. A significant increase in respiration rate also occurred at withdrawal of the left ovarian ligament $(35.5 \pm 1.65$ respirations $/ \mathrm{min})$ when compared to the first phase $(10.4 \pm 1.43$ respirations $/ \mathrm{min}, p<0.05)$. Arterial blood pressure slowly decreased throughout the intervention, but hypotension was not observed. All the bitches in the COV group had low body temperature at the end of the surgery $\left(36.1 \pm 0.18^{\circ} \mathrm{C}\right)$.

Table 1. Changes of parameters in the ovariectomy group $(n=10)$

\begin{tabular}{ccccccc}
\hline Phase & $\begin{array}{c}\text { Heart rate } \\
\text { (beats/min) }\end{array}$ & $\begin{array}{c}\text { Body } \\
\text { temperature } \\
\left({ }^{\circ} \mathbf{C}\right)\end{array}$ & $\begin{array}{c}\text { Respiratory rate } \\
\text { (respirations/ } \\
\text { min) }\end{array}$ & $\begin{array}{c}\text { Systolic } \\
\text { arterial } \\
\text { pressure } \\
(\mathbf{m m H g})\end{array}$ & $\begin{array}{c}\text { Mean } \\
\text { arterial } \\
\text { pressure } \\
(\mathbf{m m H g})\end{array}$ & $\begin{array}{c}\text { Diastolic } \\
\text { arterial } \\
\text { pressure } \\
(\mathbf{m m H g})\end{array}$ \\
\hline I & $80.5 \pm 3.14$ & $38.68 \pm 0.11$ & $10.4 \pm 1.43$ & $132.0 \pm 5.38$ & $101.2 \pm 4.18$ & $86.0 \pm 3.94$ \\
\hline II & $100.0 \pm 2.9^{*}$ & & $24.7 \pm 1.25^{*}$ & $120.0 \pm 3.33^{*}$ & $88.0 \pm 3.16^{*}$ & $70.0 \pm 3.33^{*}$ \\
III & $109.5 \pm 3.17^{*}$ & & $35.5 \pm 1.65^{*}$ & $100.5 \pm 3.69 *$ & $76.7 \pm 3.33^{*}$ & $64.5 \pm 4.38^{*}$ \\
\hline IV & $109.0 \pm 3.46^{*}$ & & $29.5 \pm 1.96^{*}$ & $94.0 \pm 3.94^{*}$ & $77.0 \pm 1.15^{*}$ & $61.0 \pm 2.11^{*}$ \\
\hline V & $110.5 \pm 2.99^{*}$ & & $35.5 \pm 1.35^{*}$ & $94.0 \pm 3.94^{*}$ & $65.8 \pm 2.94^{*}$ & $52.0 \pm 2.58^{*}$ \\
\hline VI & $110.0 \pm 3.46^{*}$ & $36.09 \pm 0.18^{*}$ & $30.0 \pm 1.94^{*}$ & $91.0 \pm 3.94^{*}$ & $57.6 \pm 1.71 *$ & $41.0 \pm 2.11^{*}$ \\
\hline
\end{tabular}

Legend: Phase I-intubation, Phase II-incision, Phase III - withdrawal of the left ovarian ligament, Phase IV - withdrawal of the right ovarian ligament, Phase V - skin suturing, Phase VI - extubation Values significantly different $(p<0.05)$ between phase I and other phases are marked with an asterisk

The bitches in COV group were asleep and did not vocalize 15 minutes postoperatively. At thirty minutes postoperatively the bitches were awake, but they could hardly raise the head and did vocalize. One hour after the surgery the bitches were awake, but their gait was unsteady, sometimes they vocalized. Three hours after the surgery, they could raise the head but their gait was still unsteady, occasionally they vocalized. At the end of observation period, that is at six hours postoperatively, they were awake and had a steady gait. The signs of severe pain were present in two bitches and moderate pain in 7 bitches (Table 2).

In bitches, which underwent laparoscopic ovariectomy, no significant changes of parameters monitored were observed intraoperatively (Table 3). All the bitches from LOV group were awake, with a steady gait and did not vocalize 30 minutes after the end of surgery. Signs of moderate pain were present in 2 bitches at 15 and in one bitch at 30 minutes postoperatively. Mild pain was present only in two bitches six hours after surgery (Table 4). 
Table 2. Postoperative total pain score in the ovariectomy group $(\mathrm{n}=10)$

\begin{tabular}{|c|c|c|c|c|c|}
\hline $\begin{array}{l}\text { Total pain } \\
\text { score }\end{array}$ & $\begin{array}{c}15 \text { minutes } \\
\text { postoperative }\end{array}$ & $\begin{array}{c}30 \text { minutes } \\
\text { postoperative }\end{array}$ & $\begin{array}{c}1 \text { hour } \\
\text { postoperative }\end{array}$ & $\begin{array}{c}3 \text { hours } \\
\text { postoperative }\end{array}$ & $\begin{array}{c}6 \text { hours } \\
\text { postoperative }\end{array}$ \\
\hline 0 & I & 1 & 1 & 1 & 1 \\
\hline $1-3$ & 5 & 3 & 3 & 2 & 1 \\
\hline 4-6 & 4 & 6 & 5 & 6 & 7 \\
\hline $7-10$ & 1 & 1 & 2 & 2 & 2 \\
\hline
\end{tabular}

Total pain score: 0 No signs of pain, 1-3 mild pain present, 4-6 presence of moderate pain, 7-9 presence of severe pain

Table 3. Changes of parameters in the laparoscopy group $(\mathrm{n}=10)$

\begin{tabular}{ccccccc}
\hline Phase & $\begin{array}{c}\text { Heart rate } \\
\text { (beats/min) }\end{array}$ & $\begin{array}{c}\text { Body } \\
\text { temperature } \\
\left({ }^{\circ} \mathbf{C}\right)\end{array}$ & $\begin{array}{c}\text { Respiratory } \\
\text { rate } \\
\text { (respirations/ } \\
\text { min) }\end{array}$ & $\begin{array}{c}\text { Systolic } \\
\text { arterial } \\
\text { pressure } \\
(\mathbf{m m H g})\end{array}$ & $\begin{array}{c}\text { Mean } \\
\text { arterial } \\
\text { pressure } \\
(\mathbf{m m H g})\end{array}$ & $\begin{array}{c}\text { Diastolic } \\
\text { arterial } \\
\text { pressure } \\
(\mathbf{m m H g})\end{array}$ \\
\hline I & $98.2 \pm 3.79$ & $38.7 \pm 0.08$ & $15 \pm 1.42$ & $129.2 \pm 2.25$ & $99.0 \pm 4.05$ & $80.0 \pm 3.33$ \\
II & $98.0 \pm 2.31$ & & $15 \pm 1.42$ & $130.8 \pm 1.82$ & $99.0 \pm 1.76$ & $93.2 \pm 1.93$ \\
III & $99.1 \pm 2.33$ & & $17 \pm 1.63^{*}$ & $132.8 \pm 2.44^{*}$ & $95.8 \pm 2.44$ & $77.4 \pm 2.63$ \\
\hline IV & $97.9 \pm 1.45$ & & $15 \pm 1.42$ & $130.8 \pm 2.44$ & $96.2 \pm 2.04$ & $79.0 \pm 2.49$ \\
V & $95.9 \pm 1.97$ & & $15 \pm 1.42$ & $130.2 \pm 3.62$ & $96.8 \pm 3.15$ & $80.0 \pm 2.98$ \\
\hline VI & $101.2 \pm 3.01$ & $38.2 \pm 0.12 *$ & $15 \pm 1.42$ & $130.2 \pm 1.39$ & $97.1 \pm 1.97$ & $80.2 \pm 1.39$ \\
\hline
\end{tabular}

Legend: Phase I - intubation, Phase II - incision, Phase III - withdrawal of the left ovarian ligament, Phase IV - withdrawal of the right ovarian ligament, Phase V - skin suturing, Phase VI - extubation Values significantly different $(\phi<0.05)$ between phase I and other phases are marked with an asterisk

Table 4. Postoperative pain score in the laparoscopy group $(n=10)$

\begin{tabular}{|c|c|c|c|c|c|}
\hline $\begin{array}{l}\text { Total pain } \\
\text { score }\end{array}$ & $\begin{array}{c}15 \text { minutes } \\
\text { postoperative }\end{array}$ & $\begin{array}{c}30 \text { minutes } \\
\text { postoperative }\end{array}$ & $\begin{array}{c}1 \text { hour } \\
\text { postoperative }\end{array}$ & $\begin{array}{c}3 \text { hours } \\
\text { postoperative }\end{array}$ & $\begin{array}{c}6 \text { hours } \\
\text { postoperative }\end{array}$ \\
\hline 0 & 1 & 1 & 2 & 6 & 8 \\
\hline $1-3$ & 8 & 9 & 8 & 4 & 2 \\
\hline 4-6 & 2 & 1 & I & I & I \\
\hline $7-10$ & / & / & / & / & / \\
\hline
\end{tabular}

Total pain score: 0 No signs of pain, 1-3 mild pain present, 4-6 presence of moderate pain, 7-9 presence of severe pain

\section{DISCUSSION}

Arterial blood pressure decreased intraoperatively in the COV group. This might be explained by the use of higher volume $\%$ of sevoflurane that was required for maintenance of surgical anaesthesia in comparison to the LOV group [14]. Respiratory 
rate increased in dogs from COV group during the withdrawal of the left ligament and thus ketamine was administered to suppress the response to the painful stimulus. Increased heart rate after the withdrawal of the first ovarian ligament was probably a consequence of response to the painful stimulus as well as ketamine, which increases the heart rate and cardiac output [15]. The difference in the length of the skin incision was significant between groups. The length of the surgical incision in COV group was between 6 and $12 \mathrm{~cm}$, and in the LOV group there where two incisions, each $1 \mathrm{~cm}$ long.

Bitches in the COV group showed a low body temperature at the end of surgery, which might be attributed to increased surface temperature losses due to evaporative loss of heat from the surgical site and sevoflurane induced vasodilatation [16]. Bitches from COV group recovered with more difficulty and woke up slowly which is in accordance with other studies $[17,18]$. Most of the bitches from the COV group felt pain of moderate intensity at the end of the six-hour observation period and required additional analgesics. The necessity of applying analgesics six hours after surgery was confirmed in a study by Lee et al. [19].

Bitches in the LOV group did not respond to the withdrawal of the ovarian ligaments and therefore there was no need for intraoperative administration of an analgesic dose of ketamine. The surgical procedure itself took less time than in the COV group as it lasted only from 15 to 20 minutes. Short anaesthesia time and closed abdomen in LOV group were probably the reasons for good maintenance of body temperature in this group of dogs [20,21]. Dogs from the LOV group were fully awake one hour after the end of surgery and moved with a steady gait. The main and most significant difference between the groups was that bitches from group LOV showed mild pain or no signs of pain at one hour postoperatively and there was no need for additional analgesia. The difference in duration between the procedures was viewed as contributing to the faster and easier recovery of bitches from the LOV group [22].

One of the important conclusions that can be drawn from this work is that in laparoscopic ovariectomy the pain is less intense when compared to conventional ovariectomy. Today, it is of paramount importance to every veterinarian practitioner to professionally and ethically perceive the presence of pain and treat it adequately. In addition to ovariectomy, other surgical interventions such as preventive gastropexy can be performed laparoscopically.

Another advantage of laparscopic surgery is a significant difference as far as the consumption of anaesthetics, analgesics, and surgical material is concerned. The use of anaesthetics in patients from LOV group was much smaller, in the sense that there was no additional intraoperative need for ketamine, as opposed to COV group where it was applied due to the presence of painful surgical stimulation. Also, the concentration of sevoflurane required to maintain surgical anaesthesia was lower in LOV group, which contributed to less hypotension due to sevoflurane. 


\section{Acknowledgements:}

This study was supported by the Ministry of Education, Science and Technological Development of the Republic of Serbia (Grant No. III46002 and Grant No. 175061).

\section{REFERENCES}

1. Shariati E, Bakhtiari J, Kgalaj A, Niasari-Naslaji A: Comparison between two portal laparoscopy and open surgery for ovariectomy in dogs. Vet Rec Forum 2014, 5(3): 219-223.

2. Howe LM: Surgical methods of contraception and sterilization. Theriogenology 2006, 66(3): 500-509.

3. Goethem BV, Okkens AS, Kirpesteijn J: Making a rational choice between ovariectomy and ovariohysterectomy in the dog: A discussion of the benefit of either technique. Vet Surg 2006, 35: 136-143.

4. Gower S, Mayhew P: Canine laparoscopic and laparoscopic-assisted ovariohysterectomy and ovariectomy. Compend Contin Educ Vet 2008, 30(8): 430-440.

5. Wildt D, Lawer DF: Laparoscopic sterilization of the bitch and queen by uterine horn occlusion. Am J Vet Res 1985, 46(4):864-869.

6. Fox SM, Mellor DJ, Stafford KJ, Lowoko CRO: The effects of ovariohysterectomy plus different combinations of halothane anaesthesia and butorphanol analgesia on behavior in the bitch. Res Vet Sci 2000, 68:265-274.

7. Austin B, Lanz OI, Hamilton SM, Broadstone RV, Martin RA: Laparoscopic ovariohysterectomy in nine dogs. J Am Anim Hosp Assoc 2003, 39(4): 391-396.

8. Bednarski R, Grimm K, Harvey R, Lukasik VM, Penn WS, Sargent B, Spelts K, American Animal Hospital Association: AAHA anesthesia guidelines for dogs and cats. J Am Anim Hosp Assoc 2011, 47(6): 377-385.

9. Ledowski T, Reimer M, Chavez V, Kapoor V, Wenk M: Effects of acute postoperative pain on catecholamine plasma levels, hemodynamic parameters, and cardiac autonomic control. Pain 2012, 153(4):759-764.

10. Martins TL, Kahvegian MA, Noel-Morgan J, Leon-Roman MA, Otsuki DA, Fantoni DT: Comparison of the effects of tramadol, codeine, and ketoprofen alone or in combination on postoperative pain and on concentrations of blood glucose, serum cortisol, and serum interleukin-6 in dogs undergoing maxillectomy or mandibulectomy. Am J Vet Res 2010, 71(9): 1019-1026.

11. Shin AC, Robertson S, Isaza N, Pablo L, Davies W: Comparison between analgesic effects of buprenorphine, carprofen, and buprenorphine with carprofen for canine ovariohysterectomy. Vet Anaesth Analg 2008, 35(1):69-79.

12. Gómez-Villamandos RJ, Redondo JI, Martín EM, Domíngues JM, Granados MM, Estepa JC, Ruiz I, Aguilera E, Santisteban JM: Romifidine or medetomidine premedication before propofol sevoflurane anaesthesia in dogs. J Vet Pharmacol Ther 2005, 28(5): 489-493.

13. Lipták T, Capík I, Ledecký V, Nagy O, Kuricová M, Tóthová C, Mad’ari A, Farbáková J, Petrovič V, Horñák S: Cardiorespiratory and hemodynamic effects of medetomidine or xylazine with atropine and diazepam premedication for total intravenous anesthesia induced and maintained with propofol/fentanyl in dogs undergoing surgery. Acta Vet.Beograd 2014, 64 (4): 466-476. 
14. Vojvodic D, Miljanovic O, Djurdjevic D, Gataric S, Stanojevic I, Obradovic D, Surbatovic M, Francuski J: Effects of different anesthetic agents on GM-CSF, MCP1, IL1 and TNF levels in rat sepsis model. Acta Vet.-Beograd 2013, 63(2-3): 125-136.

15. Patschke D, Bruckner JB, Gethmann JW, Tarnow J, Weymar A: The effect of ketamine on haemodynamics and myocardial oxygen consumption in anaesthetized dogs (autors transl). Prakt Anaesth 1975, 10(6):325-334.

16. Yamazaki M, Steikel TA, Bosnjak ZJ, Kanpine JP, Stekiel WJ: Effects of volatile anesthetic agents on in situ vascular smooth muscle transmembrane potential in resistance - and capacitance - regulating blood vessels, Anesthesiology 1998, 88: 1085-1095.

17. Davidson EB, Moll HD, Payton ME: Comparison of laparoscopic ovariohysterectomy and ovariohysterectomy in dogs. Vet Surg 2004, 33(1): 62-69.

18. Culp WT, Mayhew PD, Brown DC: The effect of laparoscopic versus open ovariectomy on postsurgical activity in small dogs. Vet Surg 2009, 38: 811-817.

19. Lee JY, Kim MC: Comparison of oxidative stress status in dogs undergoing laparoscopic and open ovariectomy. J Vet Med Sci 2014, 76(2): 273-276.

20. Kibanda JO, Gurney M: Comparison of two methods for the management of intraoperative hypothermia in dogs. Vet Rec 2012, 170(15): 392.

21. Arican M, Parlak K, İnce ME, Güzelbekteş H: Result of endoscopically assisted gastropexy in dogs. Acta Vet.-Beograd 2014, 64(2), 226-235.

22. Wagner AE, Walton JA, Hellyer PW, Gaynor JS, Mama KR: Use of low doses of ketamine administered by constant rate infusion as an adjunct for postoperative analgesia in dogs. J Am Vet Med Assoc 2002, 221(1):72-75.

\title{
UPOREDNA ANALIZA PARAMETARA INTRAOPERATIVNOG I POSTOPERATIVNOG BOLA KOD KUJA PRILIKOM LAPAROSKOPSKE I KLASIČNE OVARIEKTOMIJE
}

\author{
VASILJEVIĆ Maja, RISTANOVIĆ Dragan, JOVANOVIĆ Milan, DAVITKOV \\ Darko, BOŠNJAK Ivan, KRSTIĆ Vanja, STANIMIROVIĆ Zoran
}

Cilj studije je bio da se ispitaju parametri intraoperativnog i postoperativnog bola kod kuja prilikom laparoskopske i klasične ovariektomije. Ispitivanje je obavljeno na 20 zdravih, odraslih kuja, srednjih i velikih rasa. Sve kuje su podvrgnute istom anesteziološkom protokolu. Karprofen je kao analgetik aplikovan svim kujama preoperativno, a opšta anestezija je postignuta kombinacijom medetomidina, propofola i sevoflurana. Kuje su podeljene u dve grupe od po 10 jedinki. Prvoj grupi je rađena klasična, a drugoj grupi laparoskopska ovariektomija. Jačina intraoperativnog bola praćena je na osnovu promena sledećih parametara: pulsa, frekvence disanja, arterijskog krvnog pritiska i telesne temperature. Za procenu inteziteta postoperativnog bola korišćena je multifaktorijalna skala bola. Kod pasa kod kojih je ovariektomija rađena klasičnom metodom ustanovljeno je povećanje pulsa i frekvence disanja. Kod tih jedinki je primećeno i smanjenje arterijskog krvnog pritiska i telesne temperature. Laparoskopska ovariektomija izaziva manji intra- i postoperativni bol u odnosu na klasičnu ovariektomiju. Pored toka ukupno vreme trajanja anestezije i postoperativni oporavak su kraći kod pasa kod kojih je urađena laparoskopska ovariektomija. 